\author{
ARIEL PRZYBYŁOWICZ \\ ORCID: 0000-0003-4219-0984 \\ Uniwersytet Wrocławski
}

\title{
CO KSZTAŁTUJE PRAWO DO ZASIŁKU CHOROBOWEGO W POLSKIM I NIEMIECKIM UBEZPIECZENIU CHOROBOWYM? WYBRANE ZAGADNIENIA
}

\begin{abstract}
Abstrakt: Autor analizuje wybrane rozwiązania prawne w polskim i niemieckim ubezpieczeniu chorobowym, szukając odpowiedzi na pytanie, co determinuje kształt przyjętych rozwiązań prawnych w odniesieniu do zasiłku chorobowego. Czy polski i niemiecki ustawodawca, kształtując prawo do zasiłku chorobowego, opiera się wyłącznie na kategorii ryzyka socjalnego czasowej niezdolności do pracy, rozumianej jako niezdolność do pracy wskutek choroby pociągającej za sobą utratę zarobku, czy też posiłkuje się również innymi kryteriami? Analiza polskich i niemieckich rozwiązań prowadzi do wniosku, że ustawodawcy w wielu przypadkach odchodzą od kryterium ryzyka socjalnego, a prawo do zasiłku chorobowego determinowane jest często potrzebą, choć odejście od kryterium ryzyka socjalnego w obu ustawodawstwach ma miejsce nie zawsze w tych samych obszarach. Przeprowadzona analiza może być pomocna przy konstruowaniu prawa do zasiłku bardziej opierającego się na kryterium ryzyka socjalnego, które powinno być podstawową kategorią ubezpieczenia społecznego jako jednego z działów zabezpieczenia społecznego.
\end{abstract}

Słowa kluczowe: ubezpieczenie chorobowe, zasiłek chorobowy, ryzyko socjalne, ubezpieczenia społeczne

\section{WPROWADZENIE}

Ubezpieczenie chorobowe jest jednym z rodzajów ubezpieczeń społecznych w Polsce i w Niemczech. W obu systemach prawnych pojęcia te mają jednak różne znaczenie. Niemieckie ubezpieczenie chorobowe (Krankenversicherung) dzieli się na ustawowe ubezpieczenie chorobowe (gesetzliche Krankenversicherung; dalej: GKV) oraz prywatne ubezpieczenie chorobowe (private Krankenversicherung; dalej: PKV). Ubezpieczenie to obejmuje swym zakresem świadczenia dwojakiego rodzaju ${ }^{1}$ : świadczenia opieki zdrowotnej w razie stanu chorobowego, a zatem świadczenia udzielane w naturze (rzeczowe i w formie usług) niezależnie

1 R. Waltermann, Sozialrecht, Heidelberg 2018, s. 91; S. Muckel, Sozialrecht, München 2007, s. 146. 
od tego, czy choroba dotknęła ubezpieczonego wykonującego jakąś pracę zarobkową, a także świadczenia pieniężne dla tych ubezpieczonych, u których choroba skutkuje niezdolnością do pracy, to znaczy uniemożliwia im wykonywanie pracy zarobkowej, przede wszystkim zasiłek chorobowy (Krankengeld). Można zatem rzec, że ubezpieczenie chorobowe obejmuje zakres przedmiotowy określony w części II i III konwencji nr 102 MOP dotyczącej minimalnych norm zabezpieczenia społecznego (opieka lekarska i zasiłki chorobowe), a tym samym można przyjąć, że obejmuje socjalne ryzyko choroby rozumianej jako niezdrowie/brak zdrowia (określane tak w polskiej literaturze - między innymi J. Jończyk ${ }^{2}$ ) oraz ryzyko przejściowej niezdolności do pracy z powodu choroby ${ }^{3}$. Regulacja prawna niemieckiego ubezpieczenia chorobowego rozproszona jest w kilku aktach prawnych, z których najważniejszym jest V księga kodeksu socjalnego (Ubezpieczenie chorobowe ${ }^{4}$ ), a także pewne przepisy IV księgi kodeksu socjalnego (Przepisy wspólne ubezpieczenia społecznego) ${ }^{5}$, I księgi kodeksu socjalnego (Część ogólna) $)^{6}$, a w zakresie PKV - ustawa o umowie ubezpieczenia ${ }^{7}$.

$\mathrm{W}$ polskim prawie socjalnym ryzyka te objęte są ochroną w ramach odrębnych rodzajów ubezpieczeń. Tak zwane ubezpieczenie zdrowotne, uregulowane w ustawie z dnia 27 sierpnia 2004 roku o świadczeniach opieki zdrowotnej finansowanych ze środków publicznych ${ }^{8}$, które z formalnego punktu widzenia nie należy do ubezpieczeń społecznych ${ }^{9}$, gwarantuje świadczenia rzeczowe i usługi w razie wystąpienia choroby/niezdrowia, a zatem świadczenia określone w II części konwencji nr 102

2 J. Jończyk, Prawo zabezpieczenia społecznego, Kraków 2001, s. 18.

3 I. Jędrasik-Janowska, Pojęcia i konstrukcje prawne ubezpieczenia społecznego, Warszawa 2016, s. 210-211. Autorka dodała przymiotnik „czasowa/przejściowa” w celu odróżnienia omawianego ryzyka od niezdolności do pracy w rozumieniu przepisów ubezpieczenia rentowego. Ustawodawca w ustawie z dnia 25 czerwca 1999 roku o świadczeniach pieniężnych z ubezpieczenia społecznego w razie choroby i macierzyństwa (tekst jedn. Dz.U. z 2019 r. poz. 645 ze zm.; dalej: u.ś.p.) posługuje się pojęciem „niezdolności do pracy z powodu choroby”, a cytowany J. Jończyk określa omawiane ryzyko jako „ryzyko niezdolności świadczenia pracy lub prowadzenia działalności" - idem, op. cit., s. 17.

${ }^{4}$ Das Fünfte Buch Sozialgesetzbuch — Gesetzliche Krankenversicherung - (Artikel 1 des Gesetzes vom 20. Dezember 1988, BGBl. I S. 2477, 2482 ze zm.), https://www.gesetze-im-internet. de/sgb_5/ (dostęp: 6.12.2019); dalej: SGB V.

${ }^{5}$ Das Vierte Buch Sozialgesetzbuch - Gemeinsame Vorschriften für die Sozialversicherung — in der Fassung der Bekanntmachung vom 12. November 2009 (BGB1. I S. 3710, 3973; 2011 I S. 363), https://www.gesetze-im-internet.de/sgb_4/(dostęp: 6.12.2019); dalej: SGB IV.

${ }^{6}$ Das Erste Buch Sozialgesetzbuch - Allgemeiner Teil - (Artikel I des Gesetzes vom 11. Dezember 1975, BGB1. I S. 3015 ze zm.), https://www.gesetze-im-internet.de/sgb_1/ (dostęp: 6.12.2019); dalej: SGB I.

7 Versicherungsvertragsgesetz vom 23. November 2007 (BGB1. I S. 2631), https://www.gesetze-im-internet.de/vvg_2008/(dostęp: 6.12.2019); dalej: VVG.

8 Tekst jedn. Dz.U. z 2019 r. poz. 1373 ze zm.

9 Nie jest wskazane jako rodzaj ubezpieczenia społecznego w art. 1 ustawy z dnia z dnia 13 października 1998 roku o systemie ubezpieczeń społecznych (tekst jedn. Dz.U. z 2019 r. poz. 300 ze zm.; dalej: u.s.u.s.). 
MOP. Przysługują one ubezpieczonym niezależnie od tego, czy choroba powoduje jakiekolwiek skutki ekonomiczne (uniemożliwia zarobkowanie). W tym przypadku to choroba (stan braku zdrowia) jest ryzykiem samym w sobie. Ubezpieczenie chorobowe (ubezpieczenie w razie choroby i macierzyństwa) zapewnia wyłącznie świadczenia pieniężne, gdy choroba powoduje negatywne skutki ekonomiczne jest przeszkodą $\mathrm{w}$ wykonywaniu pracy zarobkowej. Chodzi zatem o świadczenia, o których mowa w III części konwencji nr 102 MOP. W tym wypadku ryzykiem nie jest sama choroba — jest ona przyczyną ryzyka socjalnego, którym jest właśnie niezdolność do pracy, czyli ekonomiczny skutek choroby ${ }^{10}$. Na potrzeby niniejszego opracowania należy zatem przyjąć, że treścią tego ryzyka jest niezdolność do pracy wskutek choroby pociągająca za sobą utratę zarobku ${ }^{11}$. W polskim ustawodawstwie ryzyko to zabezpieczone jest przede wszystkim zasiłkiem chorobowym oraz świadczeniem rehabilitacyjnym z ubezpieczenia chorobowego. Świadczenia te, podobnie jak zasiłek chorobowy w Niemczech, mają zastąpić (przynajmniej w części ${ }^{12}$ ) zarobki nieosiągnięte $\mathrm{z}$ powodu choroby ${ }^{13}$.

Przedmiotem badań niniejszego opracowania będzie regulacja prawna wybranych zagadnień prawa do zasiłku chorobowego w prawie polskim i niemieckim, ze szczególnym uwzględnieniem tych rozwiązań prawnych, które pozwalają określić, co w istocie kształtuje prawo do zasiłku chorobowego - czy jest to „czyste” ryzyko socjalne ${ }^{14}$, rozumiane jako zdarzenie przyszłe, niepewne, niezależne od woli człowieka i dla niego niekorzystne (przynoszące stratę) ${ }^{15}$, czy jednak również inne okoliczności determinują przyjęte rozwiązania prawne. Przede wszystkim, stosując metodę dogmatycznoprawną, dokonam analizy obowiązujących przepisów w zakresie wybranych okoliczności kształtujących prawo do zasiłku chorobowego w polskim i niemieckim ubezpieczeniu chorobowym. Umożliwi to następnie porównanie rozwiązań stosowanych przez obu ustawodawców. Takie porównanie nie tylko może mieć walor poznawczy, lecz także inspirować do wprowadzenia określonych zmian normatywnych, które pozwolą na bardziej prawidłowe ukształtowanie regulacji prawnej zasiłku chorobowego z uwzględnieniem ryzyka czasowej niezdolności do pracy jako ryzyka socjalnego. Niniejsze

10 K. Ryś, Wybrane problemy ubezpieczenia społecznego z tytułu niezdolności do pracy z powodu choroby, „Ubezpieczenia Społeczne. Teoria i praktyka” 2017, nr 3, s. 79; zob. też A. Napiórkowska, Ryzyko w ubezpieczeniu Społecznym, „Państwo i Prawo” 2012, nr 12, s. 63-64.

11 Zob. W. Szubert, Ubezpieczenia społeczne. Zarys systemu, Warszawa 1987, s. 90;

J. Piotrowski, Zabezpieczenie społeczne. Problematyka i metody, Warszawa 1966, s. 96-97.

12 Zob. też J. Jończyk, op. cit., s. 203, 205.

13 I. Jędrasik-Jankowska, Zasiłek chorobowy jako świadczenie $w$ razie czasowej niezdolności do pracy, [w:] Ryzyko niezdolności do pracy w zabezpieczeniu społecznym, red. U. Jackowiak, R. Ziółkowska, Gdańsk 2006, s. 7.

14 Szeroko na temat pojęcia ryzyka socjalnego K. Roszewska, Ryzyko niezdolności do pracy, Warszawa 2018, s. 25-54.

15 J. Jończyk, op. cit., s. 13; tak też R. Babińska-Górecka, [w:] Wielka encyklopedia prawa, t. 12. Prawo socjalne, red. H. Szurgacz, Warszawa 2017, s. 242. 
opracowanie nie ma charakteru kompleksowego. Z powodu ograniczonych jego ram i obszerności omawianych zagadnień konieczne jest ograniczenie rozważań do wybranych zagadnień i stosowanie pewnych uproszczeń (na przykład przez pominięcie wyjątków, mniej istotnych szczegółowych regulacji czy skupienie się tylko na wybranych aspektach danego zagadnienia), co jednak odnośnie do istoty przedmiotu opracowania nie ma negatywnego wpływu na wnioski.

\section{ZAKRES PODMIOTOWY ZASIŁKU CHOROBOWEGO W POLSCE I W NIEMCZECH}

Zgodnie z art. 11 u.s.u.s. ubezpieczenie chorobowe jest obowiązkowe (przymus ubezpieczenia) lub dobrowolne ${ }^{16}$. Obowiązkowo ubezpieczeniu chorobowemu podlegają między innymi pracownicy (to jest osoby wykonujące pracę w ramach stosunku pracy — art. $22 \S 1$ k.p. ${ }^{17}$ ); dobrowolnie zaś — na wniosek, po dokonaniu stosownego zgłoszenia — ubezpieczeniu chorobowemu mogą podlegać między innymi zleceniobiorcy (czyli osoby wykonujące pracę zarobkową na podstawie umów o charakterze cywilnoprawnym, takich jak zlecenie czy inne umowy o świadczenie usług, do których stosuje się przepisy kodeksu cywilnego o zleceniu), doktoranci otrzymujący stypendia doktorskie oraz osoby prowadzące pozarolniczą działalność (w tym działalność gospodarczą czy działalność artystyczną w rozumieniu art. 8 ust. 6 u.s.u.s.). Zakres podmiotowy ubezpieczenia chorobowego jest bardzo zawężony w porównaniu do pozostałych rodzajów ubezpieczenia. Analiza art. 11 u.s.u.s. prowadzi do wniosku, że jest on determinowany ryzykiem czasowej niezdolności do pracy z powodu choroby. Ubezpieczeniem tym objęte są tylko te osoby wykonujące pracę zarobkową, które wskutek wystąpienia losowego zdarzenia, jakim jest choroba, mogą stać się niezdolne do pracy i na czas choroby utracić źródło utrzymania ${ }^{18}$. Osoby podlegające ubezpieczeniom emerytalnemu i rentowym, u których ewentualna choroba nie będzie skutkowała utratą zarobków (bo ich tytuł ubezpieczenia emerytalnego i ubezpieczeń rentowych jest niezarobkowy lub odrębne ustawy przewidują innego rodzaju świadczenia na wypadek choroby), nie są objęte ubezpieczeniem chorobowym. Sam zasiłek chorobowy przysługuje natomiast wszystkim ubezpieczonym podlegającym ubezpieczeniu chorobowemu niezależnie od charakteru tego ubezpieczenia

16 A. Kaczmarek, Zakres podmiotowy ubezpieczenia chorobowego, [w:] Ubezpieczenia chorobowe, red. B. Wagner, A. Malaka, Iwonicz-Zdrój 2010, s. 37 n.

17 Ustawa z dnia 26 czerwca 1974 roku Kodeks pracy (tekst jedn. Dz.U. z 2019 r. poz. 1040 ze zm.).

18 Zob. szerzej I. Jędrasik-Jankowska, Pojęcia i konstrukcje prawne ubezpieczenia społecznego, Warszawa 2016, s. 210-212. 
(dobrowolnego czy obowiązkowego), choć dla osób ubezpieczonych dobrowolnie ustawodawca przewiduje dłuższy okres karencyjny (okres wyczekiwania) ${ }^{19}$.

GKV również przewiduje świadczenie pieniężne, gdy choroba powoduje niezdolność ubezpieczonego do pracy, w § 44 SGB V — zasiłek chorobowy (Krankengeld $)^{20}$. Nie przysługuje on jednak wszystkim ubezpieczonym, lecz jedynie osobom, które nie zostały wyraźnie wyłączone w $§ 44$ ust. 2 SGB V. Analizując grupy ubezpieczonych, dla których ustawodawca wyłączył w $\S 44$ ust. 2 pkt 1 SG V prawo do zasiłku chorobowego, można z pewnym uproszczeniem stwierdzić, że prawo do tego świadczenia wyłączono wobec tych ubezpieczonych, u których choroba nie będzie skutkowała negatywnymi konsekwencjami w zakresie uzyskiwania zarobków. Wynika to ze specyfiki niemieckiego ubezpieczenia chorobowego, które obejmuje nie tylko świadczenia pieniężne w razie czasowej niezdolności do pracy, lecz także świadczenia opieki zdrowotnej w polskim znaczeniu tego określenia. Dlatego też zasiłek z założenia przysługiwać ma, tak jak w Polsce, tylko tym ubezpieczonym, u których choroba może powodować niemożność wykonywania pracy zarobkowej, świadczenia opieki zdrowotnej zaś wszystkim ubezpieczonym niezależnie od wystąpienia negatywnych ekonomicznych skutków choroby. Innymi słowy o ile samo ubezpieczenie chorobowe w Niemczech ma szeroki zakres podmiotowy, o tyle prawo do zasiłku chorobowego ograniczone jest do niektórych kategorii ubezpieczonych, to znaczy tych, u których choroba skutkuje utratą zarobków.

Niemieckie ustawowe ubezpieczenie chorobowe jest obowiązkowe dla pracowników zatrudnionych za wynagrodzeniem ${ }^{21}$. Przedsiębiorcy (hauptberuflich selbständige Erwerbstätigkeit) nie tylko nie mają obowiązku podlegania GKV, ale nawet nie są uprawnieni do dobrowolnego przystąpienia do tego ubezpieczenia ${ }^{22}$. Zasadniczo zatem niemiecki ustawodawca nie obejmuje GKV przedsiębiorców, jak czyni to polski ustawodawca w ubezpieczeniu chorobowym (mogą się ubezpieczyć dobrowolnie bez konieczności spełniania innych dodatkowych warunków). Dla nich z założenia podstawowym systemem zabezpieczenia na wypadek choroby jest PKV. Co istotne z punktu widzenia niniejszego opracowania, przedsiębiorcom, nawet podlegającym GKV, nie przysługuje prawo do zasiłku chorobowego. Wynika to wprost z $§ 44$ ust. 2 pkt 2 SGB V z zastrzeżeniem, że przedsiębiorca może złożyć oświadczenie, że jego ubezpieczenie ma również

1990 dni nieprzerwanego podlegania ubezpieczeniu chorobowemu; dla osób ubezpieczonych obowiązkowo okres ten wynosi 30 dni (art. 4 ust. 1 u.ś.p.).

${ }^{20}$ Zasiłek ten przysługuje również w razie korzystania ze świadczeń stacjonarnych, świadczeń opieki zdrowotnej finansowanych przez kasę chorych.

${ }^{21} \mathrm{O}$ ile roczne wynagrodzenie nie przekracza określonych kwot; w razie przekroczenia obowiązek odpada i podleganie GKV staje się dobrowolne. W razie nieprzystąpienia dobrowolnie do GKV aktualizuje się obowiązek zawarcia umowy prywatnego ubezpieczenia na podstawie $\S 193$ ust. 3 VVG. Zob. R. Waltermann, op. cit., s. 85; w 2019 roku graniczna kwota wyniosła 60750 euro.

22 Chyba że spełniają warunki wskazane w $\S 9$ ust. 1 pkt 1 SGB V, przede wszystkim podlegali wcześniej obowiązkowo GKV przez okres 12 lub 24 miesięcy. 
obejmować prawo do zasiłku chorobowego. Dopiero wówczas w razie wystąpienia choroby uniemożliwiającej wykonywanie działalności zarobkowej może on uzyskać prawo do zasiłku. PKV nie obejmuje swym zakresem przedmiotowym zasiłku chorobowego (określanego w tym przypadku jako Krankentagegeld), o ile ubezpieczony nie ma dodatkowego prywatnego ubezpieczenia na wypadek utraty zarobków spowodowanych chorobą ${ }^{23}$. „Standardowe” PKV obejmuje zatem wyłącznie świadczenia związane z leczeniem (czyli stanowi odpowiednik polskiego ubezpieczenia zdrowotnego).

\section{NIEZDOLNOŚĆ DO PRACY Z POWODU CHOROBY JAKO PRZESŁANKA NABYCIA PRAWA DO ZASIŁKU CHOROBOWEGO W POLSCE I W NIEMCZECH}

Zgodnie z art. 6 ust. 1 u.ś.p. zasiłek chorobowy przysługuje ubezpieczonemu, który stał się niezdolny do pracy z powodu choroby w czasie trwania ubezpieczenia chorobowego. Podstawową przesłanką jest zatem niezdolność do pracy (aspekt ekonomiczny) spowodowana chorobą (aspekt biologiczny), która musi powstać $\mathrm{w}$ trakcie trwania ubezpieczenia chorobowego (a zatem w trakcie trwania stosunku prawnego, który stanowi tytuł ubezpieczenia chorobowego). Tym samym należy przyjąć, że podstawowa przesłanka uzyskania prawa do zasiłku chorobowego została sformułowana na podstawie kryterium ryzyka socjalnego, jakim jest przejściowa niezdolność do pracy. Na równi z niezdolnością do pracy z powodu choroby na gruncie ubezpieczenia chorobowego (art. 6 ust. 2 u.ś.p.) traktuje się niemożność wykonywania pracy:

1) w wyniku decyzji wydanej przez właściwy organ albo uprawniony podmiot na podstawie przepisów o zapobieganiu oraz zwalczaniu zakażeń i chorób zakaźnych u ludzi;

2) z powodu przebywania w:

- stacjonarnym zakładzie lecznictwa odwykowego w celu leczenia uzależnienia alkoholowego,

— szpitalu albo innym zakładzie leczniczym podmiotu leczniczego wykonującego działalność leczniczą w rodzaju stacjonarnego i całodobowego świadczenia zdrowotnego w celu leczenia uzależnienia od środków odurzających lub substancji psychotropowych;

3) wskutek poddania się niezbędnym badaniom lekarskim przewidzianym dla kandydatów na dawców komórek, tkanek i narządów.

We wskazanych okolicznościach ubezpieczeni nie mogą wykonywać pracy zarobkowej, choć jedynie w odniesieniu do pkt 2 można mówić o chorobie (uzależnienie od alkoholu czy środków odurzających/środków psychotropowych należy

$23 \S 192$ ust. 1, ust. 3 VVG; § 196 VVG. 
zakwalifikować jako chorobę z medycznego punktu widzenia $\left.{ }^{24}\right)$. W odniesieniu do pkt 1 i 3 ochrona ubezpieczeniowa uzasadniona jest podobieństwem wymienionych przeszkód w zarobkowaniu do choroby ${ }^{25}$, choć w istocie nie mamy do czynienia ze stwierdzeniem choroby. Sytuacje te powodują jednak czasową niemożność zarobkowania i powstanie uszczerbku majątkowego. Z punktu widzenia konstrukcyjnego nie można jednak mówić o ziszczeniu się ryzyka przejściowej niezdolności do pracy z powodu choroby, gdyż przyczyną przerwy w działalności zarobkowej nie jest choroba, lecz inne zdarzenie. W tym zakresie zatem prawo do zasiłku chorobowego uzasadnia raczej zaistnienie potrzeby po stronie ubezpieczonego (wywołanej inną okolicznością niż choroba) niż samo socjalne ryzyko niezdolności do pracy z powodu choroby w przyjętym $\mathrm{w}$ niniejszym opracowaniu znaczeniu ${ }^{26}$.

W Niemczech podstawowa przesłanka nabycia prawa do zasiłku chorobowego sformułowana została $\mathrm{w} \S 44$ ust. 1 SGB V. Zasiłek ten przysługuje ubezpieczonemu, którego choroba czyni niezdolnym do pracy, a także ubezpieczonemu, któremu szpital lub instytucja rehabilitacji udziela świadczeń opieki zdrowotnej na koszt kasy chorych (z wyjątkiem ubezpieczonych wskazanych w ust. § 44 ust. 2 SGB V). Zasadniczo zatem, podobnie jak w Polsce, zasiłek chorobowy przysługuje, gdy choroba uniemożliwia ubezpieczonemu wykonywanie pracy zarobkowej. Na podstawie $\S 45$ ust. 2 SGB V zasiłek chorobowy przysługuje także dawcom organów, tkanek lub krwi do separacji komórek macierzystych albo innych składników krwi, jeżeli dawstwo czyni dawcę niezdolnym do pracy, a ponadto wypłacany jest przez kasę chorych, w której ubezpieczony jest biorca (co jest konsekwencją mnogości kas chorych jako wykonawców ubezpieczenia chorobowego). Inaczej jednak niż w Polsce niemiecki ustawodawca jest bardziej konsekwentny i przesłanką uzyskania zasiłku w tym przypadku jest niezdolność do pracy wywołana dawstwem organów, tkanek czy krwi, a zatem ryzyko socjalne. Niemiecki ustawodawca przewiduje ponadto zasiłek chorobowy dla ubezpieczonego, jeżeli nadzoru, opieki lub pielęgnacji wymaga jego chore i objęte ubezpieczeniem chorobowym dziecko ${ }^{27}$, które nie ukończyło 12. roku życia, a w gospodarstwie domowym nie ma innej osoby, która mogłaby zapewnić nadzór, opiekę lub pielęgnację ( $\$ 45$ SGB V). W tym wypadku trudno mówić o ryzyku niezdolności do pracy z powodu choroby, gdyż sam ubezpieczony jest zdrowy, a pracę uniemożliwia choroba dziecka, które wymaga jego opieki, a zatem przesłanką uzyskania zasiłku cho-

${ }^{24}$ I. Jędrasik-Jankowska, Pojęcia i konstrukcje..., s. 214. Autorka trafnie zauważa, że z punktu widzenia sztuki legislacyjnej wątpliwości budzi zakwalifikowanie tych sytuacji jako zrównanych $\mathrm{z}$ niezdolnością do pracy z powodu choroby, skoro w istocie mamy do czynienia $\mathrm{z}$ chorobą.

25 Ibidem, s. 213-214.

${ }^{26} \mathrm{Na}$ temat potrzeby jako przesłanki kształtowania systemów świadczeniowych w ramach prawa socjalnego zob. szerzej K. Stopka, Świadczenia odszkodowania socjalnego w prawie polskim, Warszawa 2018, s. 268-283.

27 Chodzi o dzieci objęte współubezpieczeniem jako członkowie rodziny ubezpieczonego na podstawie $\S 10 \mathrm{SGB} \mathrm{V}$, a zatem instytucję analogiczną do występującej na gruncie polskiego ubezpieczenia zdrowotnego. 
robowego nie będzie tu ryzyko socjalne w rozumieniu przyjętym w niniejszym opracowaniu. Polski ustawodawca tego typu sytuację życiową zabezpiecza innym rodzajowo świadczeniem, to jest zasiłkiem opiekuńczym (art. 32-35 u.ś.p.), co pozwala również na wyodrębnienie odmiennego rodzajowo ryzyka socjalnego (ryzyka konieczności opieki nad dzieckiem lub innym chorym członkiem rodziny ${ }^{28}$ ), co wydaje się rozwiązaniem bardziej uwzględniającym treść ryzyka socjalnego.

Zarówno w Polsce, jak i w Niemczech niezdolność do pracy stwierdzają lekarze, biorąc pod uwagę rodzaj schorzenia i charakter wykonywanej pracy. Nie każda choroba musi bowiem powodować niezdolność do pracy ${ }^{29}$.

\section{OKRES ZASIŁKOWY W POLSCE I W NIEMCZECH}

W Polsce zasiłek chorobowy przysługuje przez okres trwania niezdolności do pracy z powodu choroby lub niemożności wykonywania pracy z przyczyn określonych w art. 6 ust. 2 u.ś.p. — nie dłużej jednak niż przez 182 dni $^{30}$. Taka regulacja realizuje zatem istotny element ryzyka czasowej niezdolności do pracy, jakim jest przejściowość (dotyczy chwilowego ograniczenia możliwości wykonywania pracy z powodu choroby, która powinna ustąpić po wdrożeniu określonych procedur medycznych). W przypadku poważniejszych zachorowań, które zmuszają do zaprzestania działalności zarobkowej w części lub całości, mamy do czynienia z ryzykiem niezdolności do pracy dla celów rentowych, objętym ochroną ubezpieczenia rentowego ${ }^{31}$. Sam przedłużający się okres trwania choroby (i niezdolności do pracy) nie powoduje jednak automatycznie przekształcenia prawa do zasiłku chorobowego w prawo do renty z tytułu niezdolności do pracy, gdyż ustawodawca przyjmuje nie tylko kryterium ilościowe, lecz także jakościowe ${ }^{32}$. Przedłużające się okresy choroby, zwłaszcza tej samej, mogą (ale nie muszą) świadczyć o poważniejszym, trwalszym charakterze niezdolności do pracy, uzasadniającej prawo do renty (lub wcześniej jeszcze świadczenia rehabilitacyjnego z ubezpieczenia chorobowego, które przysługuje w razie wyczerpania okresu zasiłku chorobowego, dalszej niezdolności do pracy i pozytywnych rokowań co do odzyskania zdolności do pracy ${ }^{33}$ ). Do wskazanego okresu zasiłkowego wlicza się wszystkie okresy nieprzerwanej niezdolności do pracy oraz okresy poprzedniej niezdolno-

28 I. Jędrasik-Jankowska, Pojęcia i konstrukcje..., s. 216-271.

29 Zob. R. Babińska-Górecka, Wykonywanie pracy zarobkowej jako przesłanka utraty prawa do zasitku chorobowego (uwagi na tle art. 17 ustawy chorobowej), „Z Zagadnień Zabezpieczenia Społecznego" 2014, nr 6, s. 10-11 i powołaną tam literaturę.

${ }^{30}$ A jeżeli niezdolność do pracy została spowodowana gruźlicą lub występuje w trakcie ciąży — nie dłużej niż przez 270 dni.

31 Zob. J. Jończyk, Prawo zabezpieczenia..., s. 17.

32 Zob. szerzej I. Jędrasik-Jankowska, Pojęcia i konstrukcje..., s. 232-233.

33 Art. 18 ust. 1 u.ś.p. 
ści do pracy spowodowanej tą samą chorobą, jeżeli przerwa pomiędzy ustaniem poprzedniej a powstaniem ponownej niezdolności do pracy nie przekraczała 60 dni (art. 9 u.ś.p.). Także te rozwiązania realizują założenia, że zasiłek chorobowy przysługuje w razie przejściowej niezdolności do pracy.

W niemieckim GKV okres zasiłkowy jest zasadniczo nieograniczony czasowo ( $\$ 48$ ust. 1 SGB V). Powołany przepis zawiera jednak bardzo istotne zastrzeżenie, że z tytułu jednej i tej samej choroby przysługuje przez okres nie dłuższy niż 78 tygodni w trzyletnim czasookresie. W razie pobierania zasiłku z tytułu niezdolności do pracy spowodowanej tą samą chorobą przez okres 78 tygodni ubezpieczony może uzyskać prawo do zasiłku w kolejnym trzyletnim okresie w razie wystąpienia tej samej choroby, o ile jednak przez okres co najmniej 6 miesięcy nie był niezdolny z powodu tej choroby i przez co najmniej 6 miesięcy wykonywał działalność zarobkową (§ 48 ust. 2 SGB V). Także niemiecki ustawodawca, określając prawo do zasiłku chorobowego, uwzględnił zatem przemijalność niezdolności do pracy jako istotny element ryzyka niezdolności do pracy jako przesłanki nabycia prawa do zasiłku chorobowego. Jak się zdaje, niemiecki ustawodawca realizuje to założenie lepiej, przyjmując ilościowe (czasowe) ograniczenie prawa do zasiłku wyłącznie w razie wystąpienia niezdolności do pracy spowodowanej tą samą chorobą, a nie ograniczając prawa do zasiłku przy różnych chorobach jako przyczynach stwierdzanych niezdolności do pracy. Nawet nieprzerwana niezdolność do pracy trwająca dłuższy okres, ale powodowana różnymi schorzeniami, które nie muszą mieć z sobą żadnego związku, umożliwia pobieranie zasiłku chorobowego, gdyż wciąż może być kwalifikowana jako przejściowa. Polski ustawodawca jest w tym zakresie bardziej restrykcyjny. O ile bowiem łączny okres pobierania świadczeń chorobowych (zasiłku chorobowego i świadczenia rehabilitacyjnego) wynosi w istocie 78 tygodni (182 dni zasiłku chorobowego + 12 miesięcy świadczenia rehabilitacyjnego), to po wyczerpaniu tego okresu nie będzie możliwe dalsze pobieranie świadczeń, choć sama niezdolność do pracy może mieć dalej przemijający charakter ${ }^{34}$. Wyłączona będzie wówczas możliwość uzyskania renty z tytułu niezdolności do pracy, a w konsekwencji ubezpieczony może pozostać bez prawa do jakichkolwiek świadczeń z ubezpieczenia społecznego.

\section{PRAWO DO ZASIŁKU CHOROBOWEGO A PRAWO DO WYNAGRODZENIA CHOROBOWEGO W POLSCE I W NIEMCZECH}

Polski ustawodawca przewiduje, że zasiłek chorobowy nie przysługuje za okresy niezdolności do pracy, w których ubezpieczony na podstawie przepisów

34 Może być nieprzerwana, spowodowana jednak różnymi, niemającymi z sobą związku schorzeniami. 
o wynagradzaniu zachowuje prawo do wynagrodzenia (art. 12 ust. 1 u.ś.p.). Okresy te wlicza się do wspomnianego okresu zasiłkowego ${ }^{35}$. Przyjęta konstrukcja prawna polega na podziale ryzyka niezdolności do pracy z powodu choroby między pracodawcę a ubezpieczonego/instytucję ubezpieczeniową ${ }^{36}$. Składka na ubezpieczenie chorobowe $(2,45 \%$ podstawy wymiaru $)$ finansowana jest $\mathrm{w}$ całości ze środków ubezpieczonego, co wynika z art. 16 ust. 2 ustawy systemowej. W zamian jednak pracodawca został zobowiązany do wypłaty pracownikowi tak zwanego wynagrodzenia chorobowego. Zgodnie z art. $92 \S 1$ k.p. za czas niezdolności pracownika do pracy wskutek choroby lub odosobnienia w związku z chorobą zakaźną — trwającej łącznie do 33 dni w ciągu roku kalendarzowego ${ }^{37}$ — pracownik zachowuje prawo do $80 \%$ wynagrodzenia, chyba że obowiązujące u danego pracodawcy przepisy prawa pracy przewidują wyższe wynagrodzenie z tego tytułu ${ }^{38}$. W 2018 roku obciążenia finansowe pracodawców z tytułu absencji chorobowej wyniosły ponad 6,9 mld zł, wydatki zaś FUS z tytułu zasiłku chorobowego - 11,5 mld zł ${ }^{39}$, co pokazuje, że partycypacja pracodawców w ryzyku niezdolności do pracy z tytułu choroby ma znaczny wymiar finansowy. Wskazana regulacja dotyczy wyłącznie pracowników. W przypadku zleceniobiorców ciężar finansowania świadczeń pieniężnych z tytułu niezdolności do pracy spoczywa w całości na instytucji ubezpieczeniowej, co zresztą może być jedną z przyczyn nadużywania zatrudnienia cywilnoprawnego. Również w przypadku przedsiębiorców dobrowolnie podlegających ubezpieczeniu chorobowemu zasiłek już od pierwszego dnia niezdolności do pracy jest wypłacany przez ZUS.

W Niemczech prawo do zasiłku chorobowego jest zawieszone w okresie pobierania przez pracownika wynagrodzenia chorobowego na podstawie przepisów prawa pracy. Chodzi o przepisy ustawy o wynagrodzeniu za pracę w dni świąteczne i w razie choroby ${ }^{40}$. Ustawa ta przewiduje obowiązek pracodawcy do wypłaty wynagrodzenia chorobowego przez okres 6 tygodni, o ile niezdolność ta nie jest zawiniona przez pracownika ( $\$ 2$ ust. $1 \mathrm{EFZG).} \mathrm{Wynagrodzenie} \mathrm{to} \mathrm{wynosi} \mathrm{obecnie} \mathrm{tyle,}$ ile pracownik by otrzymał, gdyby wykonywał pracę, a zatem w istocie $100 \%$ wynagrodzenia ( $\$ 4$ ust. 1 EFZG), choć pierwotnie wynosiło ono $80 \%$ wynagrodzenia, a $100 \%$ jedynie w wyjątkowych przypadkach ${ }^{41}$. Inaczej niż w Polsce uzasadnienia

35 D. Dzienisiuk, Prawo pracy a prawo ubezpieczeń społecznych, Warszawa 2016, s. 305.

36 T. Bińczycka-Majewska, Wynagrodzenie za czas niezdolności do pracy z powodu choroby, „Prawo Pracy” 1995, nr 8, s 13-14; Ł. Pisarczyk, Ryzyko pracodawcy, Warszawa 2008, s. 238.

37 W przypadku pracownika, który ukończył 50. rok życia, trwającej łącznie do 14 dni w ciągu roku kalendarzowego.

38 Art. $92 \S 1$ k.p. w wyjątkowych przypadkach przewiduje również wynagrodzenie chorobowe w wysokości $100 \%$ wynagrodzenia.

39 https://www.zus.pl/documents/10182/167627/Biuletyn_WOJ_K4_2018/3e549502-26927c36-804f-943a2845833e (dostęp: 6.12.2019).

40 Entgeltfortzahlungsgesetz vom 26. Mai 1994 (BGB1. I S. 1014, 1065), https://www.gesetze-im-internet.de/entgfg/index.html (dostęp: 6.12.2019); dalej: EFZG.

41 W. Däubler, Das Arbeitsrecht 2. Leifaden für Arbeitnehmer, Hamburg 1998, s. 493. 
nie należy szukać w tym, że pracodawca nie finansuje ze swych środków składki na ubezpieczenie chorobowe, gdyż w Niemczech składka ta jest ponoszona w równych częściach przez pracodawcę i pracownika ${ }^{42}$. $Z$ tego punktu widzenia pracodawcy niemieccy podwójnie obciążeni są ryzykiem niezdolności pracownika do pracy partycypując w składce oraz wypłacając wynagrodzenie chorobowe.

Wyłączenie/zawieszenie prawa do zasiłku chorobowego w okresie pobierania wynagrodzenia chorobowego znajduje uzasadnienie w treści ryzyka przejściowej niezdolności do pracy. Skoro w tym przypadku choroba nie powoduje utraty zarobków, nie realizuje się również ekonomiczny aspekt choroby. Niewypłacanie zasiłku chorobowego w okresie pobierana wynagrodzenia chorobowego jest zatem prawidłowym i słusznym rozwiązaniem.

\section{PRAWO DO ZASIŁKU CHOROBOWEGO PO USTANIU TYTUŁU UBEZPIECZENIA W POLSCE I W NIEMCZECH}

W Polsce możliwe jest pobieranie zasiłku chorobowego mimo ustania ubezpieczenia chorobowego. Po pierwsze, w razie stwierdzenia niezdolności do pracy z powodu choroby w trakcie trwania ubezpieczenia zasiłek będzie przysługiwał również wówczas, gdy ustanie tytuł ubezpieczenia (na przykład rozwiązana zostanie umowa o pracę). Istotne jest zatem, aby ryzyko socjalne ziściło się w okresie trwania ubezpieczenia. Ustanie tytułu ubezpieczenia nie ma wpływu na nabyte już prawo do świadczenia. Po drugie, art. 7 u.ś.p. przewiduje możliwość nabycia prawa do zasiłku nawet $\mathrm{w}$ razie stwierdzenia niezdolności do pracy po ustaniu tytułu ubezpieczenia. Zgodnie z tym przepisem zasiłek chorobowy przysługuje również osobie, która stała się niezdolna do pracy po ustaniu tytułu ubezpieczenia chorobowego, jeżeli niezdolność do pracy trwała bez przerwy co najmniej 30 dni i powstała nie później niż w ciągu 14 dni od ustania tytułu ubezpieczenia chorobowego ${ }^{43}$. Taka regulacja powoduje, że naruszona zostaje istota zasiłku, który nie zabezpiecza w tym wypadku skutków choroby w sferze ekonomicznej — przy ustaniu tytułu ubezpieczenia nie ma bowiem zarobków, które miałyby być rekompensowane zasiłkiem chorobowym. W tym zatem zakresie polski ustawodawca prawo do zasiłku przyznaje nie ze względu na wystąpienie ryzyka czasowej niezdolności do pracy z powodu choroby; w tym wypadku prawo do zasiłku wynika raczej z zaistnienia określonej potrzeby (co może potwierdzać także art. 13 ust. 1 pkt 2 u.ś.p., stanowiący, że prawo do zasiłku po ustaniu tytułu ubezpieczenia nie przysługuje temu, kto kontynuuje działalność zarobkową lub podjął działalność

$42 \S 249$ ust. 1 SGB V; zob. R. Waltermann, op. cit., s. 81.

43 Lub wyjątkowo w okresie 3 miesięcy w razie choroby zakaźnej, której okres wylęgania jest dłuższy niż 14 dni, lub innej choroby, której objawy chorobowe ujawniają się po okresie dłuższym niż 14 dni od początku choroby. 
zarobkową stanowiącą tytuł do objęcia obowiązkowo lub dobrowolnie ubezpieczeniem chorobowym albo zapewniającą prawo do świadczeń za okres niezdolności do pracy z powodu choroby). Takie rozwiązanie nie jest jednak prawidłowe z punktu widzenia konstrukcji prawnej zasiłku chorobowego, a świadczenie zapewniające źródło utrzymania powinno być wypłacane z innego systemu świadczeniowego (na przykład w ramach wsparcia bezrobotnych). Wprawdzie de lege lata przesłanką uznania za bezrobotnego jest zdolność do pracy ${ }^{44}$ i nienabycie prawa do zasiłku chorobowego ${ }^{45}$, ale ustawodawca nie wykazuje w tym przypadku konsekwencji. Zgodnie $\mathrm{z}$ art. 33 ust. 4 pkt 9 u.p.z. powstanie niezdolności do pracy z powodu choroby u bezrobotnego nie skutkuje pozbawieniem go statusu bezrobotnego, chyba że niezdolność ta trwa nieprzerwanie 90 dni, a co istotne - nie ma wpływu na możliwość pobierania zasiłku dla bezrobotnych (art. 75 u.p.z.) ${ }^{46}$.

Przepisy SGB V nie przewidują możliwości nabycia prawa do zasiłku chorobowego po ustaniu tytułu zatrudnienia. Osoby te mogą wprawdzie nadal podlegać ubezpieczeniu chorobowemu nawet mimo niepodjęcia innej pracy zarobkowej $\mathrm{z}$ uwagi na jego charakter $\mathrm{w}$ niemieckim systemie socjalnym na podstawie $\S 5$ ust. 1 pkt 13 SGB V (kontynuowanie ubezpieczenia) ${ }^{47}$, ale $\S 44$ ust. 2 SGB V wyraźnie wyłącza prawo do zasiłku chorobowego dla tych ubezpieczonych. Pewne odstępstwo od tej zasady wynika z § 46 SGB V w zw. z § 192 § 1 pkt 2 SGB V. $\mathrm{W}$ przypadku ubezpieczonych, u których niezdolność do pracy powstałaby w terminie miesiąca od ustania poprzedniej niezdolności do pracy, o ile spowodowane są one tą samą chorobą, ustawodawca przewidział prawo do zasiłku chorobowego nawet $\mathrm{w}$ razie ustania tytułu ubezpieczenia uprawniającego do tego zasiłku (samo ubezpieczenie trwa wówczas w ramach instytucji członkostwa w kasie chorych zgodnie z powołanym $\S 192 \S 1$ pkt 2 SGB V). W innych przypadkach nie jest możliwe nabycie prawa do zasiłku po ustaniu tytułu ubezpieczenia uprawniającego do tego zasiłku. Podobnie jednak jak w Polsce, możliwe jest dalsze pobieranie zasiłku, jeżeli prawo do niego powstało jeszcze w trakcie trwania tego tytułu.

\section{PRAWO DO ZASIŁKU CHOROBOWEGO DLA UBEZPIECZONEGO POSIADAJACCEGO USTALONE PRAWO DO EMERYTURY LUB RENTY W POLSCE I W NIEMCZECH}

W Polsce status emeryta lub rencisty zasadniczo nie ma wpływu na możliwość nabycia prawa do zasiłku chorobowego. Emeryt/rencista wykonujący pracę

44 Rozumiana również jako zdolność do pracy wynikająca ze stanu zdrowia - Z. Góral, [w:] Ustawa o promocji zatrudnienia i instytucjach rynku pracy. Komentarz, red. Z. Góral, Warszawa 2016, s. 62-63.

45 Art. 2 ust. 1 pkt 2 ustawy z dnia 20 kwietnia 2004 roku o promocji zatrudnienia i instytucjach rynku pracy, tekst jedn. Dz.U. z 2019 r. poz. 1482 (dalej: u.p.z.).

${ }^{46}$ K. Jaworska, Socjalne traktowanie bezrobocia, Olsztyn 2017, s. 55.

${ }^{47}$ R. Waltermann, op. cit., s. 85. 
zarobkową, ubezpieczony z tytułu wykonywania tej pracy, ma takie samo prawo do zasiłku chorobowego w razie wystąpienia czasowej niezdolności do pracy jak każdy inny ubezpieczony, choć ma inne źródło utrzymania w postaci emerytury lub renty. Polski ustawodawca w tym zakresie kształtuje prawo do zasiłku chorobowego wyłącznie na podstawie ryzyka. W omawianym przypadku ubezpieczony nie może świadczyć pracy czy wykonywać innej pracy zarobkowej, wskutek czego doznaje uszczerbku majątkowego (brak zarobków z tej pracy). Zasiłek ma ten uszczerbek częściowo łagodzić i bez znaczenia jest to, że ubezpieczony pobiera inne świadczenia $z$ ubezpieczenia społecznego. Oceniam to rozwiązanie jako prawidłowe, gdyż w tym wypadku ryzyko niewątpliwie się realizuje i pozbawia ubezpieczonego części środków do życia, które by uzyskał, gdyby nie choroba.

Inaczej przedstawia się sytuacja emerytów i rencistów w Niemczech. Ubezpieczeni, którzy uzyskują prawo do renty z tytułu całkowitej niezdolności do pracy, pełnej emerytury, uposażenia w stanie spoczynku, świadczenia przedemerytalnego i innych zbliżonych rodzajowo świadczeń, z dniem nabycia tych świadczeń tracą prawo do zasiłku chorobowego i nie mogą już go nabyć (§ 50 ust. 1 SGB V). Niemiecki system nie dopuszcza zatem łączenia świadczeń emerytalno-rentowych z zasiłkiem chorobowym, jeżeli świadczenia emerytalno-rentowe przysługują w pełnym wymiarze. $W$ przypadku jednak pobierania niepełnych świadczeń, na przykład emerytury częściowej lub renty z tytułu częściowej niezdolności do pracy, zasiłek chorobowy zmniejsza się o kwotę emerytury/renty (§50 ust. 2 SGB V). Formalnie przysługują wówczas dwa świadczenia, ale w praktyce ich wysokość będzie wynosić tyle, ile wynosiłby zasiłek chorobowy. Niemiecki ustawodawca w tym zakresie bardziej bierze pod uwagę potrzebę niż samo ryzyko socjalne przejściowej niezdolności do pracy. To świadczenie długoterminowe z założenia powinno stanowić źródło utrzymania i w przypadku pracujących emerytów/ rencistów pobierających pełne świadczenia emerytalne lub rentowe ewentualny uszczerbek majątkowy powstały wskutek niezdolności do pracy spowodowanej chorobą nie zostanie zrekompensowany mimo ziszczenia się ryzyka.

\section{WNIOSKI}

Dokonana analiza wybranych polskich i niemieckich rozwiązań prawnych pozwala na sformułowanie wielu szczegółowych wniosków.

1. Zasadniczo zasiłek chorobowy zarówno w Polsce, jak i w Niemczech chroni socjalne ryzyko niezdolności do pracy z powodu choroby, przy czym ryzyko to rozumiane jest jako ekonomiczny skutek choroby, to jest niemożność uzyskiwania zarobku z wykonywanej pracy zarobkowej właśnie z powodu występującego naruszonego stanu zdrowia. Wynika to $\mathrm{z}$ rozumienia tego ryzyka w art. 14 konwencji nr 102 MOP, zgodnie z którym przedmiot ochrony powinien obejmować 
niezdolność do pracy wskutek choroby pociągającą za sobą utratę zarobku. Celem zasiłku jest zatem (częściowa) rekompensata zarobku utraconego z powodu choroby przejściowo uniemożliwiającej wykonywanie pracy zarobkowej stanowiącej tytuł ubezpieczenia chorobowego.

2. Polskie ryzyko czasowej niezdolności do pracy obejmuje wyłącznie sytuację samego ubezpieczonego, któremu stan zdrowia uniemożliwia przejściowo wykonywanie pracy. Choroba innej osoby, która powoduje konieczność sprawowania nad nią opieki przez ubezpieczonego, jest odmiennym treściowo ryzykiem socjalnym, objętym ochroną ubezpieczenia chorobowego w ramach zasiłku opiekuńczego. Takie rozwiązanie jest zatem właściwe z punktu widzenia treści ryzyka socjalnego. Czasowa niezdolność do pracy powinna dotyczyć samego ubezpieczonego, a konieczność sprawowania opieki jest rodzajowo innym ryzykiem, nawet jeśli wystąpiła wskutek choroby dziecka. Niemiecki ustawodawca natomiast w przypadku konieczności sprawowania opieki nad dzieckiem z powodu jego choroby przyznaje prawo do zasiłku chorobowego, nie wyodrębniając innego rodzajowo ryzyka socjalnego, choć w tym przypadku trudno mówić o niezdolności do pracy spowodowanej chorobą u samego ubezpieczonego.

3. Zarówno polskie, jak i niemieckie rozwiązania prawne potwierdzają, że z założenia jest to świadczenie krótkoterminowe, a przy długotrwałej niezdolności do pracy ubezpieczony po wyczerpaniu okresu zasiłkowego powinien uzyskać prawo do świadczeń o charakterze długoterminowym (renta). Regulacja niemiecka wprost przewidująca tutaj ograniczenie czasowe zasiłku do 78 tygodni wyłącznie w razie niezdolności do pracy spowodowanej jedną i tą samą chorobą wydaje się bardziej adekwatnym rozwiązaniem (mając na uwadze treść chronionego ryzyka) niż przepisy polskie, które w istocie umożliwiają z jednej strony znaczne przedłużanie okresu zasiłkowego poprzez „manipulowanie” jednostkami chorobowymi powodującymi niezdolność do pracy i przerwami pomiędzy poszczególnymi niezdolnościami do pracy, a z drugiej strony w razie różnych przyczyn niezdolności do pracy, występujących jednak nieprzerwanie, uniemożliwiają pobieranie zasiłku przez okres dłuższy niż 182 dni (wyjątkowo 270 dni), choć niezdolność w istocie ma przemijający charakter. W Niemczech nieprzerwana niezdolność do pracy nawet dłuższa niż 78 tygodni nie wyłącza prawa do zasiłku, jeżeli przyczyny chorób są różne. Rozwiązanie niemieckie wydaje się bardziej odpowiadać treści ryzyka czasowej niezdolności do pracy.

4. Za zrywające z kryterium ryzyka socjalnego należy uznać rozwiązania, w których prawo do zasiłku chorobowego może zostać przyznane po ustaniu tytutu ubezpieczenia. Widoczne jest to w polskim ustawodawstwie, które sankcjonuje nabycie tego prawa nawet mimo zachorowania po upływie znacznego okresu od ustania tytułu ubezpieczenia (art. 7 u.ś.p.). Zerwanie z ryzykiem socjalnym polega na tym, że zasiłek jest wypłacany, choć choroba nie powoduje utraty zarobków. W tym zakresie uprawnienie do zasiłku chorobowego determinowane jest nie ryzykiem socjalnym, ale potrzebą. W takich sytuacjach bardziej właściwe byłoby 
przyznawanie prawa do zasiłku dla bezrobotnych zamiast zasiłku chorobowego, co byłoby bardziej konsekwentnym i spójnym systemowo rozwiązaniem, a wymagałoby nieznacznej interwencji ustawodawczej. W praktyce, $\mathrm{z}$ uwagi na znaczną różnicę w wysokości zasiłku chorobowego i zasiłku dla bezrobotnych, wiele osób tracących pracę woli korzystać z zasiłku chorobowego, choć w rzeczywistości nie występuje u nich niezdolność do pracy. Regulacje niemieckie należy uznać za bardziej spójne i odpowiadające treści ryzyka socjalnego. Ustawodawca zasadniczo w ogóle nie przewiduje możliwości nabycia prawa do zasiłku chorobowego po ustaniu tytułu ubezpieczenia $\mathrm{z}$ jednym wyjątkiem przewidzianym w $§ 46 \mathrm{SGB}$ V, gdzie wymagana jest jednak niezdolność do pracy powstała nie później niż w ciągu miesiąca od poprzedniej niezdolności do pracy i muszą być one spowodowane tą samą chorobą. Ochrona przed ryzykiem niezdolności do pracy z powodu choroby po ustaniu tytułu ubezpieczenia zapewniona jest przede wszystkim poprzez wypłatę zasiłku dla bezrobotnych (§ 146 SGB III — Leistungsfortzahlung).

5. Inaczej w obu ustawodawstwach traktowana jest możliwość pobierania zasiłku chorobowego przez osoby mające ustalone prawo do emerytury lub renty. Ustawodawca niemiecki taką możliwość wyraźnie wyłącza (z wyjątkiem osób pobierających niepełne świadczenia emerytalno-rentowe), w prawie polskim nie ma przeszkód w pobieraniu obu świadczeń tak długo, jak emeryt/rencista ma tytuł ubezpieczenia. Dopiero ustanie tytułu ubezpieczenia wyłącza prawo do zasiłku chorobowego. Polski zasiłek jest zatem bardziej ukształtowany na podstawie kryterium ryzyka, a posiadanie innego źródła utrzymania (emerytury/renty) nie ma znaczenia. Inaczej traktuje tę sytuację ustawodawca niemiecki, co pozwala przyjąć, że w tym zakresie prawo do zasiłku w Niemczech bardziej uzależnione jest od potrzeby niż od samego ryzyka.

Podsumowując, można dojść do ogólniejszej konkluzji, że choć ryzyko socjalne traktowane jest powszechnie jako czynnik determinujący kształt ochrony socjalnej w ubezpieczeniach społecznych, to w przypadku zasiłku chorobowego wyraźnie widać, że w wielu miejscach jego regulacja prawna ukształtowana została nie tylko na podstawie kryterium ryzyka socjalnego (ryzyka czasowej niezdolności do pracy), lecz także na podstawie kryterium potrzeby, odrywając niejako prawo do zasiłku chorobowego od samego zaistnienia ryzyka socjalnego, najpewniej z przyczyn politycznych, społecznych czy fiskalnych. Co istotne, analiza polskich i niemieckich rozwiązań uzasadnia postawienie tezy, że jest to nie tylko polska specyfika, ale również w innych ustawodawstwach, w których system zabezpieczenia społecznego oparty jest na ubezpieczeniach społecznych, kategoria ryzyka socjalnego jako przesłanki kształtującej system świadczeń podlega korekcie z uwzględnieniem kategorii potrzeby. Pojawia się jednak pytanie, czy systemy świadczeniowe ubezpieczenia społecznego powinny być kształtowane z uwzględnieniem innych kryteriów niż samo tylko ryzyko socjalne, zwłaszcza potrzeb, niekiedy oderwanych całkowicie od kategorii ryzyka socjalnego? W modelowym założeniu wystąpienie ryzyka socjalnego powinno skutkować zaistnie- 
niem potrzeby, ale przedstawiona analiza jednego ze świadczeń z ubezpieczenia społecznego pozwala stwierdzić, że często tak nie jest. $Z$ tego względu niezbędne są dalsze, pogłębione badania nad przesłankami kształtowania systemów świadczeniowych zabezpieczenia społecznego, a zwłaszcza rolą ryzyka socjalnego i potrzeby w poszczególnych częściach tego systemu. Niniejszej opracowanie ma stanowić przyczynek do tej dyskusji.

\section{WHAT SHAPES THE RIGHT TO SICKNESS ALLOWANCE IN POLISH AND GERMAN SICKNESS INSURANCE? SELECTED ISSUES}

\section{Summary}

The author analyzes selected legal solutions in both Polish and German sickness insurance, trying to find the answer to the following question - what determines the shape of these legal solutions concerning sickness allowance? Do the Polish and German legislators base only on the category of social risk of temporary incapacity for work (understood as incapacity for work caused by illness and resulting in loss of earnings), or do they also use other criterions? The analysis of Polish and German solutions leads to the conclusion that in many cases both legislators deviate from social risk as a criterion that shapes sickness allowance and the right to this allowance is often determined by the need. However, the departure from the criterion of social risk in sickness allowance in both legislations does not always occur in the same areas. The analysis can be helpful in constructin the right to sickness allowance based more on the criterion of social risk, which should constitute the basic category of social insurance as one of the parts of social security.

Keywords: sickness insurance, sickness allowance, social risk, social insurances

\section{BIBLIOGRAFIA}

Babińska-Górecka R., Wykonywanie pracy zarobkowej jako przesłanka utraty prawa do zasiłku chorobowego (uwagi na tle art. 17 ustawy chorobowej), „Z Zagadnień Zabezpieczenia Społecznego" 2014, nr 6.

Bińczycka-Majewska T., Wynagrodzenie za czas niezdolności do pracy z powodu choroby, „Prawo Pracy" 1995, nr 8.

Däubler W., Das Arbeitsrecht 2. Leifaden für Arbeitnehmer, Hamburg 1998.

Dzienisiuk D., Prawo pracy a prawo ubezpieczeń społecznych, Warszawa 2016.

Jaworska K., Socjalne traktowanie bezrobocia, Olsztyn 2017.

Jędrasik-Janowska I., Pojęcia i konstrukcje prawne ubezpieczenia społecznego, Warszawa 2016.

Jędrasik-Jankowska I., Zasiłek chorobowy jako świadczenie $w$ razie czasowej niezdolności do pracy [w:] Ryzyko niezdolności do pracy w zabezpieczeniu społecznym, red. U. Jackowiak, R. Ziółkowska, Gdańsk 2006.

Jończyk J., Prawo zabezpieczenia społecznego, Kraków 2001.

Joussen J., [w:] SGB V. Gesetzliche Krankenversicherung, Kommentar, red. U. Becker, T. Kingreen, www.beck-online.beck.de.

Kaczmarek A., Zakres podmiotowy ubezpieczenia chorobowego, [w:] Ubezpieczenia chorobowe, red. B. Wagner, A. Malaka, Iwonicz-Zdrój 2010. 
Muckel S., Sozialrecht, München 2007.

Napiórkowska A., Ryzyko w ubezpieczeniu społecznym, „Państwo i Prawo” 2012, nr 12.

Piotrowski J., Zabezpieczenie społeczne. Problematyka i metody, Warszawa 1966.

Pisarczyk Ł., Ryzyko pracodawcy, Warszawa 2008.

Roszewska K., Ryzyko niezdolności do pracy, Warszawa 2018.

Ryś K., Wybrane problemy ubezpieczenia społecznego z tytułu niezdolności do pracy z powodu choroby, „Ubezpieczenia Społeczne. Teoria i praktyka” 2017, nr 3.

Stopka K., Świadczenia odszkodowania socjalnego w prawie polskim, Warszawa 2018.

Szubert W., Ubezpieczenia społeczne. Zarys systemu, Warszawa 1987.

Tischler B., [w:] BeckOK Sozialrecht, red. C. Rolfs, R. Giesen, R. Kreikebohm, P. Udsching, wyd. 52, https://beck-online.beck.de/.

Ustawa o promocji zatrudnienia i instytucjach rynku pracy. Komentarz, red. Z. Góral, Warszawa 2016.

Waltermann R., Sozialrecht, Heidelberg 2018.

Wielka encyklopedia prawa, t. 12. Prawo socjalne, red. H. Szurgacz, Warszawa 2017. 